\title{
Formulation of Crude Enzymes from Bacillus sp. MTS for Cleaning Solution
}

\author{
Rahayu $\mathrm{S}^{1}$, Suhartono $\mathrm{MT}^{2}$, Suryapratama $\mathrm{W}^{1}$ \\ ${ }^{1)}$ Faculty of Animal Science, Jenderal Soedirman University \\ Jl. Dr. Soeparno Purwokerto 53123, Central Java, Indonesia \\ ${ }^{2)}$ Department of Food Science and Technology, Faculty of Agricultural Technology \\ Bogor Agricultural University, Jl. Raya Darmaga Kampus IPB, Bogor 16680, Central Java, Indonesia \\ sirahayu27@gmail.com
}

\begin{abstract}
Edible bird's nest (EBN) as a kind of functional food has high economic value depending on the quality such as color and hygiene. The purpose of this research was to find the optimum condition for application of keratinolytic enzymes of Bacillus sp. MTS in cleaning EBN. Activating agents for both enzymes were cation divalents, EDTA, reducing agents, organic solutions, and antibacterial agents. Additive compounds that able to increase keratinase activity were used to make cleaning solution and they were tested on EBN and human hair.

Alcoholic solutions (25\% ethanol, $25 \%$ methanol, $25 \%$ glycerol), and some divalent metallic ions $\left(\mathrm{Ca}^{2+}, \mathrm{Mg}^{2+}, \mathrm{Mn}^{2+}, \mathrm{Zn}^{2+}\right)$ were able to increase keratinase while disulfide reductase was solely activated by $0.05 \mathrm{mM}$ EDTA. The activity of both enzymes was inhibited by $\mathrm{NaCl}$ and $\mathrm{Na}$-azide. The activity of keratinase of Bacillus sp. MTS in cleaning solution formulated in this research was 2-3 fold as much as control (crude extract) in human hair substrates. Glycerol and cations divalent increasing 2-3 fold keratinase activity in cleaning solution. The solution was successfully applied to cleaning EBN with weight loss approximately 2.3-2.5\%.
\end{abstract}

Key Words: Keratinase, Bacillus, Cleaning, Edible Bird's Nest

\section{INTRODUCTION}

Edible bird's nest (EBN) contains the saliva of swiftlets birds. Two types of EBN, the white-nest produced by Aerodramus fuciphagus and the black-nest by Aerodramus maximus (Goh et al. 2001). The EBNs contain high quality nutrients, protein, carbohydrate, iron, inorganic salts and fiber, and bilieve to function as antiaging, anticancer, immunity enhancing agent, inhibit influenza virus infection and improve respiratory and digestive problems (Marcone 2005; Hamzah et al. 2013; Huda et al. 2008; Wu et al. 2010; Ma \& Liu 2012). The EBNs have is a good economic value namely 20 million and 10 million rupiahs per $\mathrm{kg}$ for white nest and red nest, respectively depending on the quality (Koon \& Cranbrook 2002). The primary factor of EBN quality is color and hygiene, therefore the whiter and cleaner EBN, the higher is the price.

The steps in cleaning EBN is a tedious work for being meticulous and perseverant to obtain high quality product. Koon \& Cranbrook (2002) informed that it takes eight hours to have someone clean 10 nests through soaking process in cleaning solution. The solution, however, cannot wash away the bird's feather that is stuck inside the nest; therefore, it takes a time-consuming manual process to singly discard the feathers using pincers.

The commonly used cleaning solution among the farmers/collectors is chemical-based solution containing hydrogen peroxide $\left(\mathrm{H}_{2} \mathrm{O}_{2}\right)$ known as whitening/bleaching agent. Replacing the chemicals in cleaning process with natural body-safe bleaching namely protease enzyme is one of the solution. Several alkaline proteases from bacillus have been purified and characterized (Bhaskar et al. 2007; Doddapaneni et al. 2007, Padmapriya et al. 2012; Nadeem et al. 2013).We had isolated a feather degrading bacteria and it was referred 
to Bacillus sp. MTS (Rahayu et al. 2010) .This bacillus was mesophillic aerobic, and very effective in degrading whole chicken feather. This activity appears to be related to the extracellular keratinase and disulfide reductase enzymes. The crude extract from the bacteria has shown capable of degrading whole chicken feathers, silk, cocoon, hair and fish scales (Rahayu et al. 2010). The purified enzymes of Bacillus sp. MTS worked optimally at alkaline $\mathrm{pHs}$, at $\mathrm{pH}$ 8.0-12.0 for keratinase, and at $\mathrm{pH}$ 8.0-10.0 for disulfide reductase. Optimum temperature for the extracellular keratinase was at $40-70^{\circ} \mathrm{C}$, while that for disulfide reductase was $35^{\circ} \mathrm{C}$ (Rahayu et al. 2012). We attempted to apply these enzymes to solve the problem of contaminating feather that stuck in the edible bird's nest.

In the present study, we report the effect of several compounds in a cleaning formula containing keratinolytic enzymes and testing the formula to clean EBN. This cleaning solution is expected to be environment-friendly and the enzymatic hydrolysis can shorten the cleaning process of EBN.

\section{MATERIAL AND METHODS}

\section{Growth conditions and enzymes production}

The aerobic mesophilic Bacillus sp. MTS was used in these experiments. Its screened and isolated from Tangkuban Perahu crater West Java-Indonesia.The agar medium for culture maintenance pursuant to Macedo et al. (2005) with few modification viz contained $0.6 \%$ crushed dried feather (powder). For enzyme production, $250 \mathrm{ml}$ medium containing several inorganic salts with $1.0 \%$ chicken feather powder was used as substrate (Lin et al. 2001), $\mathrm{pH}$ was adjusted to7.5. Incubation was carried out in a $11 \mathrm{flask}$ at $37^{\circ} \mathrm{C} 100 \mathrm{rpm}$ for 48 hour. After incubation the culture was strained and centrifuged at $4000 \mathrm{~g} 4^{\circ} \mathrm{C}$ for 10 minutes to harvest the extracellular enzymes.

\section{Protein and enzymes assay}

Protein concentration was measured by Bradford's method, using bovine serum albumin as the standard protein (Waterborg 2002).

Keratinase activity was measured according to Walter (1984) using $1 \%$ feather powder in Tris/ $\mathrm{HCl}(50 \mathrm{mM}, \mathrm{pH} 8.0)$ as substrate and absorbance of the samples were read at $660 \mathrm{~nm}$. A tyrosine standard curve was made for quantification. One unit of enzyme activity was assigned as the amount of enzyme which liberate $1 \mathrm{mmol}$ tyrosine in one min.

Disulfide reductase activity was assayed as described by Serrano et al. (1984) with a few modifications. Enzyme was mixed with $500 \mu \mathrm{l}$ of Tris/HCl buffer $(0.13 \mathrm{mM}, \mathrm{pH} 9.0)$ containing $0.05 \mathrm{mM}$ oxidized glutathione (GSSH) and $0.05 \mathrm{mM}$ EDTA then incubated at room temperature for $10 \mathrm{~min}$. After centrifuged at $1000 \mathrm{~g} 4^{\circ} \mathrm{C}$ for $10 \mathrm{~min}$, the action product was detected by addition of DTNB (dithiobis-nitrobenzoic acids). Absorbance was measured at $405 \mathrm{~nm}$ after $2 \mathrm{~min}$ of stable color development (Rahayu et al. 2012).

\section{Effect of additives compound}

Additives compound tested were divalent cations $\left(\mathrm{Mg}^{++}, \mathrm{Zn}^{++}, \mathrm{Ca}^{++}, \mathrm{Mg}^{++}\right)$, EDTA (ethylenediaminetetraacetic acid), reducing agents viz. dithiothreitol (DTT) and $\beta$ mercaptoethanol (BMT). Organic solvents tested were ethanol, methanol, glycerol and tween 20 and antibacterial agents namely $\mathrm{NaCl}$ and $\mathrm{Na}$-azide. Various additives and concentration were tested and observed for the effect on keratinase and reductase activity. 
A concentration to increase enzyme activity was chosen to formulate with the crude extract of Bacillus sp. MTS as the cleaning solution formula.

\section{Cleaning formulation}

The detergent formulations were prepared by mixing a 1 liter crude extract of Bacillus sp. MTS with $2 \%$ (v/v) glycerol, $2 \mathrm{mM} \mathrm{CaCl}_{2}, 2 \mathrm{mM} \mathrm{MgCl}_{2}, 2 \mathrm{mM} \mathrm{ZnCl} 2$ and 5 $\mathrm{mM} \mathrm{MnCl}$, the experiments were done with $0.16 \mathrm{U} / \mathrm{mg}$.

\section{Cleaning test}

Cleaning formula was tested on human hair and it was performed at $50^{\circ} \mathrm{C}$ for 0,20 , 40, 60 and 90 minutes. Hydrolyzed keratin products were then measured using a spectrophotometer to obtain the exact time and temperature to react cleaning solution with substrate. The solution was also tested for cleaning whole EBN. The first step, EBN was cleaned with aquadest and then $25 \%$ ethanol. Hereafter, itwas dipped in cleaning solution, then left at room temperature for 10 minutes and incubated at $50^{\circ} \mathrm{C}$ for 20 minutes. After repealing the feather, EBN was dried on $40^{\circ} \mathrm{C}$ for 40 hours. EBN was weighed before and after cleaning processes.

\section{RESULTS AND DISCUSSION}

\section{Effect of several compound to keratinase and disulfide reductase activity}

Proteases have extensive applications in a range of industrial products and processes including detergent, food, pharmaceuticals, tannery, waste treatments, resolution of amino acid mixtures, silk and silver extractionfrom used X-ray films (Rao et al. 1998). Keratinase is known as keratinolytic protease capable of binding and hydrolyzing solid substrate like feather or hair. This capability is important since detergent enzyme is required to react with protein substrate (keratin) sticking on fabric such as collar (Gupta \& Ramnani 2006).

Activity of keratinolytic enzymes in crude extract of Bacillus sp. MTS was increased by $25 \%(\mathrm{v} / \mathrm{v})$ ethanol and methanol, the increased activity was $49 \%$ and $46 \%$ for ethanol and methanol, respectively, higher than that of control (Figure 1). Ethanol and methanol are two additives extensively used as cleaning solution. Ethanol is also used as antimicrobial agent to kill or inhibit the growth of disease and odor-stimulating microbe. Economy and toxicity consideration has made ethanol chosen in cleaning solution of edible bird's nest.

Glycerol concentration of $25 \%$ can increase keratinase activity as much as $24 \%$ higher than that of control, while Tween 20 inhibited activity of keratinase Bacillus sp. MTS (Figure 2). Protein stability has an important role in keeping biological function of the protein for example during protein design, refolding and storage. Glycerol has long been used to protect enzyme activity and native protein structure against denaturation. Glycerol as reported by Meng et al. (2004) is able to increase structure of native creatin kinase. Glycerol enhanced the keratinase activity at concentration of $25 \%$ whereas Tween 20 inhibited its activity. Tween 20 is a nonionic detergent, used extensively for solubilization of membrane proteins and their biochemical characterization. Figure 1B showed that Tween-20 was ineffective for this purpose, therefore it could not be used as additive for cleaning solution. 


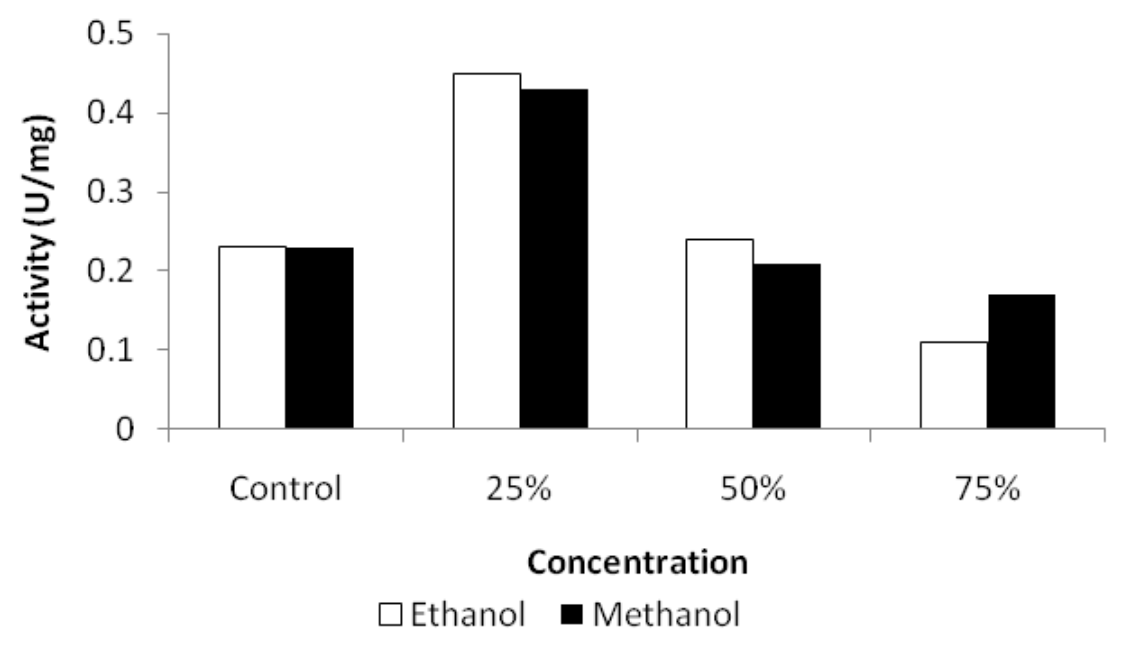

Figure 1. Effect of ethanol and methanol on keratinase activity of Bacillus sp. MTS

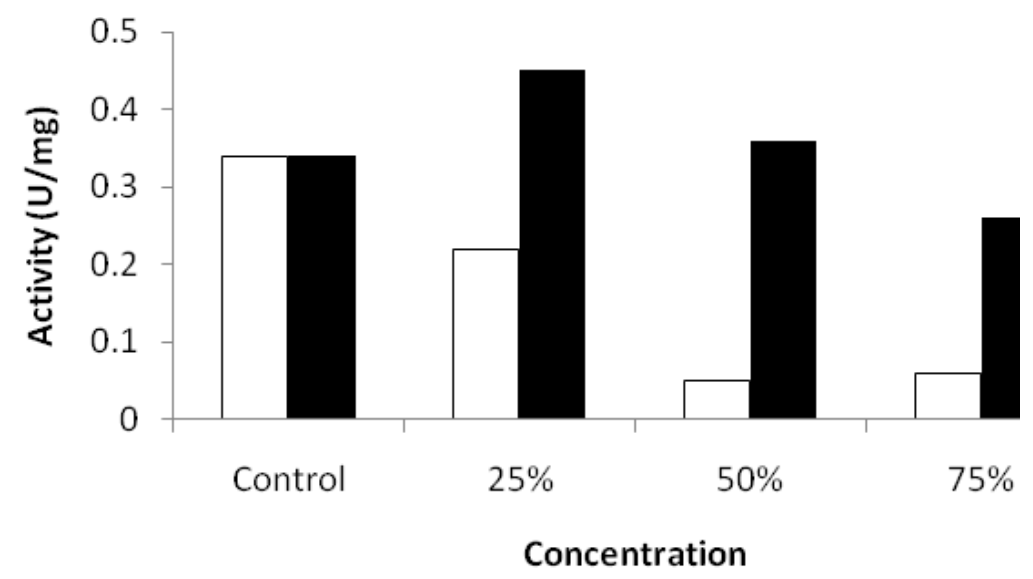

$\square$ Tween $20 \quad$ alycerol

Figure 2. Effect of tween 20 and glycerol on keratinase activity of Bacillus sp. MTS

Reducing agents viz dithiotreitol (DTT) and and $\beta$-mercaptoethanol (BMT) significantly affected keratinase activity. When the enzyme reacted with reducing agent $\left(\mathrm{E}^{*}\right)$, hydrolyzed product drastically decreased, indicating the enzyme damage. However, when substrate (chicken feather) was pre-incubated with reducing agent before being reacted with enzyme $\left(\mathrm{E}+\mathrm{S}^{*}\right)$, hydrolyzed product increased (Figure 3). DTT and BMT significantly affected keratinase activity. Several researches reported factors of disulfide bond reduction in the activity of keratin-user microorganism. Bacillus sp. MTS produces keratinase and disulfide reductase, and the reaction of both enzymes results in drastic increase of keratinolytic activity (more than 20 fold) compared to sole keratinase (Rahayu et al. 2012). It showed that keratinase affinity is higher when keratine substrate has priorly been reduced by either reducing agent or reductase disulfide enzyme. 


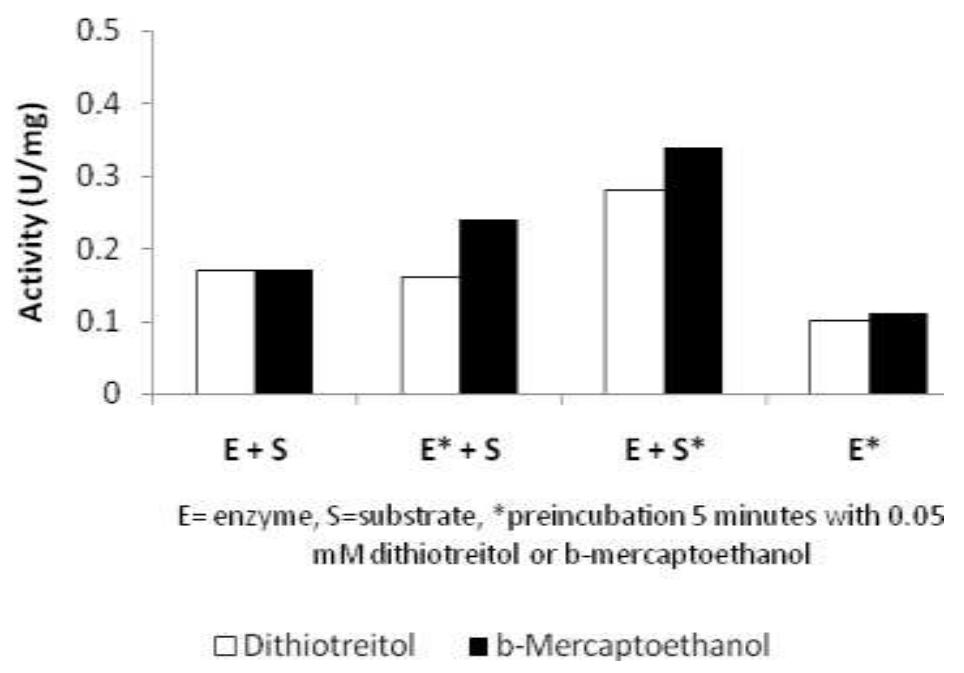

Figure 3. Effect of reducing agents on keratinase activity of Bacillus sp. MTS

For maximum activity, protease alkali needs cation divalent such as $\mathrm{Ca}^{2+}, \mathrm{Mg}^{2+}$ and $\mathrm{Mn}^{2+}$ or the combined cations. Cation is also needed to increase thermal stability of the alkaline protease of Bacillus. Cation protects enzyme from thermal denaturation effect and importantly maintain active enzyme conformation at high temperature (Rao et al. 1998). Some cations increase the keratinase activity of Bacillus sp. MTS at different concentration. At $2 \mathrm{mM}$ concentration $\mathrm{Ca}^{2+}, \mathrm{Mg}^{2+}$ and $\mathrm{Zn}^{2+}$ cation increases keratinase activity as much as $266 \%, 266 \%$ and $166 \%$, respectively. While $\mathrm{Mn}^{2+}$ at $5 \mathrm{mM}$ concentration increases keratinase activity to $360 \%$, higher than that of control (Figure 4). Rahayu et al. (2010) informed that Bacillus sp. MTS produced sixth proteases, their molecular weights are 17, 25, 32, 53, 96 and >97 kD. Keratinase Bacillus sp. MTS activated by $\mathrm{Ca}^{2+}, \mathrm{Mg}^{2+}$ and $\mathrm{Zn}^{2+}$ (Fig.4), this result is in line with Bernard (2010) that $>97$ $\mathrm{kDa}$ and $96 \mathrm{kDa}$ Bacillus sp. MTS protease were activated by $\mathrm{Mg}^{2+}$ and $\mathrm{Mn}^{2+}$ and inhibited by $2 \mathrm{mM}$ EDTA. Its indicated that both protease belong to metal protease.

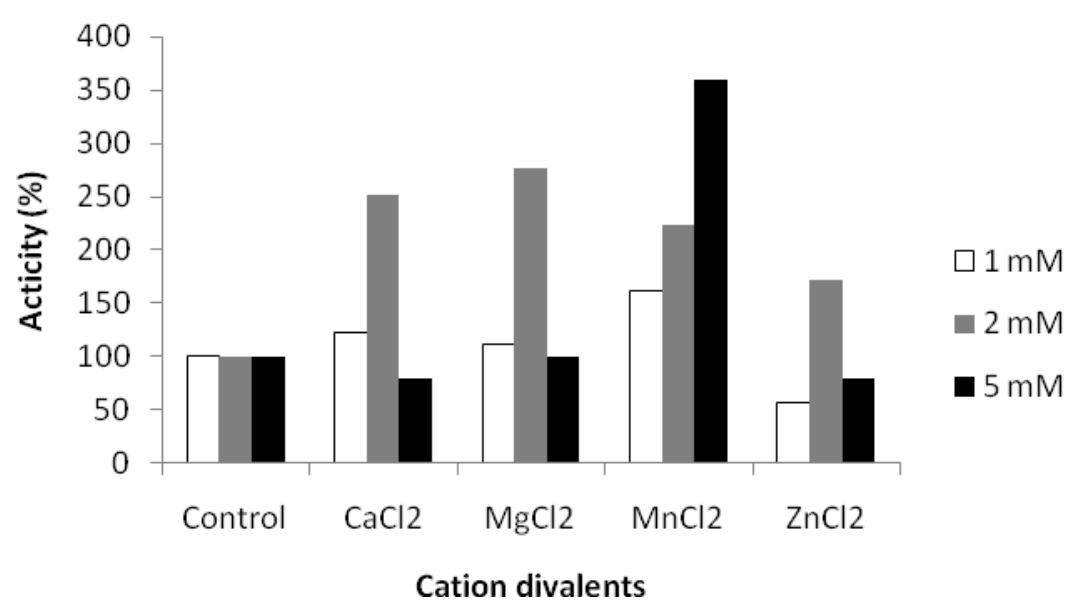

Figure 4. Effect of divalent cation on keratinase activity of Bacillus sp. MTS

The effect of additives to Bacillus sp. MTS reductase activity showed that reductase enzyme was obstructed by various tested additives. Activity increase was observed when reductase was reacted with $0.05 \mathrm{mM}$ EDTA (Table 1). Reductase enzyme (E.C. 1.6.4) is 
active enzyme that catalyzes reduction of disulfide bonds and both are included in oxidoreductase. The active site of thiol-disulfide oxidoreductase bears Cys-Xxx-YyyCystmotifs and both residual cysteine contribute to oxidized disulfide cycle and reduced thiol (redox reactions) (Erlendsson et al. 2004). EDTA as chelate agent made reductase active site work optimally in hydrolyzing disulfide bonds in keratin structure, resulting in 10 fold increase of hydrolysis product. Inorganic ions could relate to protein side chain or interact with the active site in which these interactions might not affect the structure but facilitate or complicate substrate molecule to be or relate with enzyme active site (CornishBowden \& Cardenas 1987). The interrupted interaction between substrate and enzyme active site caused the catalytic activity of enzyme decrease.

Tabel 1. Effect of several compounds on reductase activity of Bacillus sp. MTS

\begin{tabular}{|c|c|c|}
\hline Compound & 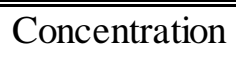 & "Activity (\%) \\
\hline \multirow[t]{4}{*}{ EDTA } & $0.00 \mathrm{mM}$ & 100 \\
\hline & $0.05 \mathrm{mM}$ & 1025 \\
\hline & $0.25 \mathrm{mM}$ & 0 \\
\hline & $0.50 \mathrm{mM}$ & 0 \\
\hline \multicolumn{3}{|l|}{ Alcohol } \\
\hline Ethanol & $25 \%$ & 25 \\
\hline Methanol & $25 \%$ & 0 \\
\hline Glycerol & $25 \%$ & 95 \\
\hline \multicolumn{3}{|l|}{ Cations } \\
\hline \multirow[t]{4}{*}{$\mathrm{NaCl}$} & $0 \%$ & 100 \\
\hline & $5 \%$ & 30 \\
\hline & $10 \%$ & 0 \\
\hline & $20 \%$ & 0 \\
\hline \multirow[t]{4}{*}{$\mathrm{ZnCl}_{2}$} & $0 \mathrm{mM}$ & 100 \\
\hline & $1 \mathrm{mM}$ & 58 \\
\hline & $2 \mathrm{mM}$ & 20 \\
\hline & $3 \mathrm{mM}$ & 8 \\
\hline \multirow[t]{4}{*}{$\mathrm{MgCl}_{2}$} & $0 \mathrm{mM}$ & 100 \\
\hline & $1 \mathrm{mM}$ & 38 \\
\hline & $2 \mathrm{mM}$ & 0 \\
\hline & $3 \mathrm{mM}$ & 0 \\
\hline \multirow[t]{4}{*}{$\mathrm{CaCl}_{2}$} & $0 \mathrm{mM}$ & 100 \\
\hline & $1 \mathrm{mM}$ & 42 \\
\hline & $2 \mathrm{mM}$ & 16 \\
\hline & $3 \mathrm{mM}$ & 0 \\
\hline
\end{tabular}

Based on the test on various additives towards keratinase activity and reductase, one formula of cleaning solution for edible bird's nest was composed. The formula was then tested on human hair at $50^{\circ} \mathrm{C}$ at various incubation periods. Keratinase in the formula was generally 2-3 times higher than that of control (Figure 6). 


\section{Effect of several compound to activity of keratinase in cleaning solution}

Bacillus sp. MTS produces six protease molecules in its cell-free filtrates, two of which are kreatinase. Various types of keratinase in Bacillus sp. MTS enable the bacteria to degrade keratin substrate such as chicken feather, human hair, cocoon, silk, fish scale and horn (Rahayu et al. 2010). Edible bird's nest is mainly composed of glycoprotein with carbohydrate components of $9 \%$ sialic acid, $7.2 \%$ galactosamine, $5.3 \%$ glucosamine, $16.9 \%$ galactose and $0.7 \%$ fructose. Protein of edible bird's nest is mainly composed of serine amino acid, threonine, aspartic acid glutamate acid, proline and valine (Goh et al. 2001). Marcone (2005) reported that edible bird's nest contained fat (0.14-1.28\%), ash (2.1\%), carbohydrate (25.62-27.26\%) and protein (62-63\%). Furthermore, $10 \%$ feather was found stuck in the nest. Protein substrate and keratin in edible bird's nest enabled enzyme in cleaning solution to function well and produce hydrolysis.

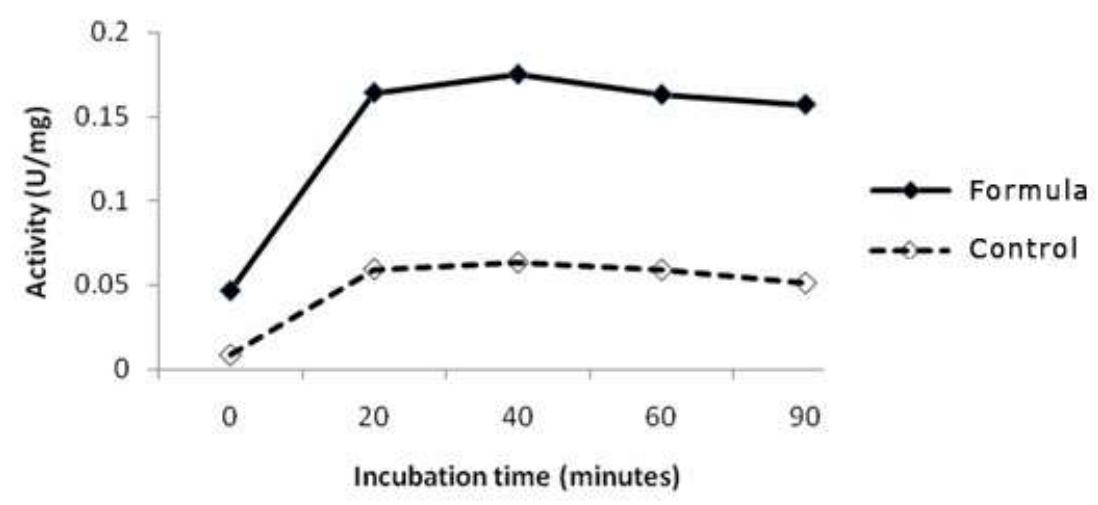

Figure 5. Keratinase activity in the cleaning solution on human hair

Keratinase activity of Bacillus sp. MTS in human hair was higher (Figure 6). Cysteine content in keratin was approximately $8 \%$ and absent in other proteins, while cysteine content in human hair was double of that in chicken feather (15.6-21.2\% vs $7.05-12.2 \%)$ (Wilson \& Lewis 2006). Keratin structure became very solid due to disulfide bridge between two amino acids (cysteine). Keratinase and reductase disulfide of Bacillus sp. MTS was observed to perform specific and synergic hydrolysis in peptide and disulfide bonds of human hair. Specificity of the two enzymes resulted in higher substrate hydrolysis on human hair than on edible bird's nest (data not showed). However, it resulted in beneficial effect as cleaning solution because low keratinase activity would prevent edible bird's nest from protease enzyme breakdown.
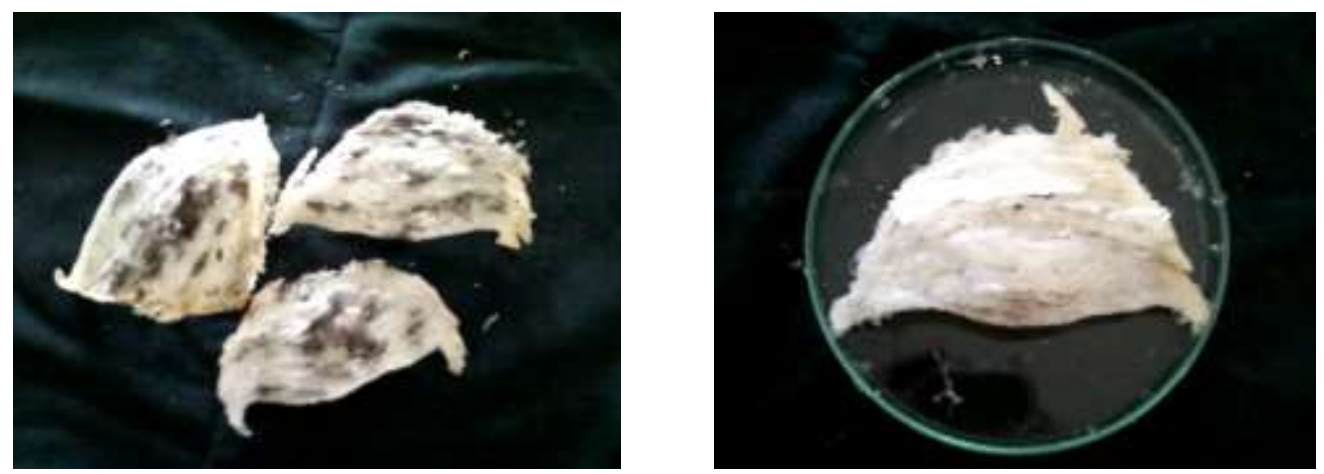

Figure 6. Edible bird's nest unprocessed (left) and processed (right) 
Cleaning edible bird's nest (EBN) need several steps before its cleaned by enzymes viz in dip several times using aquadest, $25 \%$ ethanol and enzyme solution. Aquadest and $25 \%$ ethanol removing the dust and faeces on the EBN, it's also preparing EBN for enzyme activity. Then it's incubated at room temperature for 10 minutes and $50^{\circ} \mathrm{C}$ for 20 minutes after immertion in enzyme solution. These incubation processes will provide opportunities the enzymes for loosening the bond between feather and EBN. The next stage was taken away the bird's feather that is stuck inside the nest using feather Plucker. All steps effectively cleaning EBN, it's appeared white and neat (figure 6). This cleaning process demonstrated that keratinolytic enzymes in solution capabilities to clean EBN, the weight loss of EBN was 2.3-2.5\% approximately (data not showed).

\section{CONCLUSION}

Keratinase in crude extract of Bacillus sp. MTS was activated by $25 \%$ ethanol, $25 \%$ methanol, $25 \%$ glycerol, and metal $\mathrm{Ca}^{2+}, \mathrm{Mg}^{2+}, \mathrm{Mn}^{2+}, \mathrm{Zn}^{2+}$ and it was inhibited by $\mathrm{NaCl}$ and Na-azide. While reductase disulfide enzyme was solely activated by $0.05 \mathrm{mM}$ EDTA.

Keratinase activity of Bacillus sp. MTS in cleaning solution formula increased 2-3 fold compared to that of control (crude extract) in human hair substrates. The solution was successful to clean EBN with a weight loss of approximately $2.3-2.5 \%$.

\section{ACKNOWLEDGEMENT}

This research was financially supported by Ministry of Research and Technology Indonesia pass through Incentive Research SiNas programme. Thanks to Ika Malikah, Anastasia and Megahwati Effendy for their practical support.

\section{REFERENCES}

Bernand SA. 2010. Purification and characterization keratinase from Bacillus sp. MTS.[Thesis]. [Bogor (Indonesia)]: Bogor Agricultural University.

Bhaskar N, Sudeepa ES, Rashmi HN, Sevi AT. 2007. Partial purification and characterization of protease of Bacillus proteolyticus CFR3001 isolated from fish processing waste and its antibacterial activities. Biores Technol. 98:2758-2764.

Cornish-Bowden A, Cardenas ML. 1987: Chemistry of enzyme. In: Kennedy JF, editor. Biotechnology: Enzymes Technology. Vol. 7a. Weinheim (Germany): VCH Verlagsgesellschaft $\mathrm{mbH}$.

Doddapaneni KK, Tatineni R, Vellanki RN, Gandu B, Panyaia NR, Chakli B, Mangamoori LN. 2007. Purification and characterization of two novel extracellular alkaline proteases from Serratiarubidaea. Process Biochem. 42:1229-1236.

Erlendsson LS, Moller M, Hederstedt L. 2004. Bacillus subtilis StoA is a thiol-disulfide oxidoreductases important for spore cortex synthesis. J Bacteriol. 186:6230-6238.

Goh DL, Chua KY, Chew FT, Liang RC, Seow TK, Ou KL, Yi FC, Lee BW. 2001. Immunochemical characterization of edible bird's nest allergens. J Allerg Clin Immunol. 107:1082-1088.

Goh DLM, Chua KY, Chew FT, Liang RCMY, Seow TK, Ou KL. 2001. Immunochemical characterization of edible bird's nest allergens. J Allerg Clin Immunol. 107:1082-1088.

Gupta R, Ramnani P. 2006: Microbial keratinases and their prospective applications: an overview. Appl Microbiol Biotechnol. 70:21-33. 
Hamzah Z, Ibrahim NH, Jaafar MN, Lee B-B, Hashim O, Hussin K. 2013. Nutritional properties of edible bird nest. J Asian Sci Res. 3:600-607.

Koon LC, Cranbrook Earl of. 2002: Swiftlets of Borneo-Builders of edible nests. Sabah (Malaysia): Natural History Publication (Borneo) SDN., B.H.D. (p. 1-171).

Ma F, Liu D. 2012. Sketch of the edible bird's nest and its important bioactivities. Food Res Int 48:559-567.

Marcone MF. 2005. Characterization of the edible bird's nest the "Caviar of the East". Food Res Int. 38:1125-1134.

Meng FG, Hong YK, He HW, Lyubarev AE, Boris I. Kurganov, Yan YB, Zhou HM. 2004. Osmophobic effect of glycerol on irreversible thermal denaturation of rabbit creatine kinase. Biophys J. 87:2247-2254.

Nadeem M, Javed IQ, Quratulain S, Muhammad G. (2013): Purification and characterization of an alkaline protease from Bacillus licheniformis UV-9 for detergent formulations. Songklanakarin J Sci Technol. 35:187-195.

Nurul Huda MZ, Zuki ABZ, Azhar K, Goh YM, Suhaimi H, Awang Hazmi AJ. 2008. Proximate, elemental and fatty acid analysis of pre-processed edible birds' nest (Aerodramusfuciphagus): a comparison between regions and type of nest. J Food Technol. 6:39-44.

Padmapriya B, Rajeswari T, Nandita R, Raj F. 2012. Production and purification of alkaline serine protease from marine Bacillus species and its application in detergent industry. Eur J Appl Sci. 4:21-26.

Rahayu S, Dahrul S, Antonius S, Maggy TS. 2010. Preliminary studi on keratinase from two Indonesian isolates. J Anim Prod. 12:60-68.

Rahayu S, Dahrul S, Maggy TS. 2012. Degradation of keratin by keratinase and disulfide reductase from Bacillus sp. MTS of Indonesian origin. J Biocatal Agric Biotechnol. 1 No. 1. DOI: 10.1016/j.bcab.2012.02.001.

Rao MB, Tanksale AM, Ghatge MS, Deshpande VV. 1998. Molecular and biotechnological aspects of microbial proteases. Microbiol Mol Biol Rev. 62:597-635.

Serrano A, Rivas J, Losada M. 1984. Purification and properties of glutathione reductase from cyanobacterium Anabaena sp. Strain 7119. J Bacteriol.158:317-324.

Skrzydlewska E, Roszkowska A, Moniuszko-Jakoniuk J. 1999. A comparison of methanol and ethanol effects on the activity and distribution of lysosomal proteases. Pol J Env Stud. 8:251257.

Walter H-E. 1984. Proteinases (protein as substrates). Method with haemoglobin, casein and azocoll as substrate. In: Bergmeyer J, Grassl M, editors. Methods of Enzymatic Analysis. 3rd edition. Weinheim (Germany): Verlag Chemie. p. 270-278.

Wilson RH, Lewis HB. 2006. The cystine content of hair and epidermal tissues. Available at www.jbc.org/content/73/2/543.full.pdf (accessed February 12, 2008).

Wu YJ, Chen Y, Wang B, Bai LQ, Han WR, Ge YQ. 2010. Application of SYBR green PCR and 2DGE methods to authenticate edible bird's nest food. Food Res Int. 43:2020-2026.

\section{DISCUSSION}

\section{Questions}

1. When you treatment with reducing agent, how is the activity of the enzyme? 
2. Is there any effect for the quality of nest?

\section{Answers}

1. Specific character of peptide disulfideis will be broken by reducing agent

2. No, because the formula just for cleaning 